\title{
The Monday effect and the Johannesburg Stock Exchange: revisited
}

\author{
Sinclair Davidson* \& Steven Meyer \\ Department of Business Economics, University of the Witwatersrand, Private Bag 3, P.O. Wits 2050, Republic of South Africa
}

\author{
Received November 1992, accepted June 1993
}

\begin{abstract}
The Monday effect is an anomaly that has defied explanation. It has been found to be present in major stock exchanges around the world. Bhana found evidence in favour of this anomaly in the share returns on the Johannesburg Stock Exchange (JSE). In this article the Monday effect on the JSE is reinvestigated in a later period. The methodology employed is superior to that of previous studies. It appears that the Monday effect is no longer present in the pattern of share retums on the JSE. The results of the article suggest that the original methodology creates a bias in favour of finding a Monday effect. Evidence in favour of the trading time hypothesis is found, indicating that no equity growth occurs over weekends.
\end{abstract}

Die Maandag-effek is ' $n$ anomalie wat enige verklaring te bowe gaan. Dit is teenwoordig by die vernaamste effektebeurse dwarsoor die wêreld. Bhana het bewyse van hierdie anomalie in die aandele-winste op die Johannesburgse Effektebeurs (JEB) gevind. In hierdie artikel word die Maandag-effek op die JEB opnuut ondersoek, maar in 'n latere tydperk, terwyl die metodologie wat gevolg word 'n verbetering is op dié van vorige studies. Dit wil voorkom asof die Maandag-effek nie meer teenwoordig is in die patroon wat die aandele-winste op die JEB inneem nie. Die resultate van die artikel suggereer dat die oorspronklike metodologie 'n vooroordeel getoon het ten gunste van die bestaan van so 'n effek. Bewyse word gevind ten gunste van die handelstydhipoteses, wat aandui dat geen aandele-groei oor naweke plaasvind nie.

*Author to whom correspondence should be addressed.

\section{Introduction}

The investigation of anomalies within the capital asset pricing model (CAPM) has given rise to a wealth of literature using American data. Indeed, academics such as Donald Keim have made their careers in the area. In the past few years, a great deal of replicative research has been conducted in South Africa, using data from the Johannesburg Stock Exchange (JSE). The interesting result of this research has been that, with two exceptions, the various CAPM anomalies are absent from our market (see generally Bradfield, 1989 and Page \& Palmer, 1991). One of those exceptions is the study done by Bhana (1985) into the Monday effect. It is the purpose of this article to reinvestigate the Monday effect on the JSE, using both parametric and non-parametric tests.

We will show that while the Monday effect may have existed in the past, it is no longer present in the pattern of JSE daily retums. The methodology that we use is superior to that employed by previous researchers. As a result, we are able to comment on the return generating process and on the faulty use of statistical analysis within financial economics.

The layout of this article is as follows: In the next section, we shall consider the theoretical background to the Monday effect. In the third section, we shall present the methodology and results of our tests. The article will be concluded with a discussion of the implications of our results and a conclusion.

\section{Theoretical considerations to the Monday effect}

Fama describes an efficient market as one 'in which prices provide adequate signals for resource allocation ... investors can choose among the securities that represent ownership of firm's activities under the assumption that security prices at any time "fully reflect" all available information' (1970: 183).
Given the assumption that market equilibrium can be stated in terms of expected returns and the following condition holds, the market is said to reflect all relevant information:

$$
E\left(p_{j, t+1} \mid \Phi_{l}\right)=p_{j, l}\left[1+E\left(r_{j, l+1} \mid \Phi_{\nu}\right)\right] .
$$

That is the expected price of share $\mathrm{j}$ at time $\mathrm{t}+1$ given the information set $\Phi$ at time $h$ should be equal to the price of share $\mathbf{j}$ at time $t$, plus the expected retum of share $j$ (this expected retum includes dividends). If the information set, $\Phi$, were to change between time $h$ and time $t+1$, then we would expect a change in share price greater than the expected rate of retum on share $j$. If, however, the information set $\Phi$ was to remain unchanged between time $t$, and $t+1$, then given an efficient market we would expect the following condition to hold:

$$
\begin{aligned}
& \text { If: } X_{j, l+1}=p_{j, l+1}-E\left(p_{j, l+1} \mid \Phi_{l}\right) \\
& \text { then: } E\left(X_{j, l+1} \mid \Phi_{1}\right)=0 .
\end{aligned}
$$

The efficient market hypothesis (EMH) states that (2) will hold as long as no new information becomes available to the market.

The Monday effect violates this definition of efficient markets. It states that if the period we are considering is the weekend, (i.e. Friday close to Monday close), then (2) becomes:

$E\left(X_{j, t+1} \mid \Phi_{V}\right)<0$.

It must be emphasized that there is no theoretical reason for this being so. Indeed, Seligman (1983: 93) refers to this phenomena as being 'bizarre'. There is no reason why Monday's return should be negative. There is, however, good 
reason why it should be positive. Indeed, there are theoretical reasons why the weekend retum should be three times as great as those of the rest of the week.

The efficient market hypothesis posits that information drives share prices. Fama (1965: 55) argues that as political and economic news is generated in continuous time, that the share retum generating process also operates in real time and not in trading time. Due to the fact that the market is closed, holding a position over the weekend involves a three-day investment whereas any other day it would only be a one-day investment. In order to test the real time hypothesis, Fama (1965: 56) calculates the weekend variance and weekday variances in returns for eleven shares. If the real time hypothesis is correch, then the weekend variance should have been approximately three times as great as the weekday variances. He found that the weekend variance was just $22 \%$ greater than the weekday variance. Fama (1965) does not seem to be overly interested in this result and does not pursue it.

It can be said that the Monday effect was discovered jointly by French (1980) and Gibbons \& Hess (1981). French (1980) set out to determine whether or not the stock retum generating process operated continuously or only during trading hours. In order to discover which process was at work, he examined the share returns for the five trading days of the week. If the continuous time hypothesis is correct, the mean return for Monday should be three times as great than for other days (Fama [1965] only considered variance and did not investigate the mean returns). If, on the other hand, the trading time hypothesis is valid then the returns for Mondays should be no different than that of any other day (French, 1980: 56).

The results of studying the daily retums (returns were defined as capital gains and dividends) of the Standard and Poor composite portfolio for the period 1953-1977, were surprising. French $(1980: 56)$ reports that the data were inconsistent with both hypotheses. He divided the 25 year period into five five-year sub-periods and found the same result for each period - the Monday return was negative (on average) and lower than the average return for any other day (French, 1980: 57-59).

In order to test this result for significance, French (1980: 60-61) specifies two regression models. The first for the trading time hypothesis is:

$R_{t}=\alpha+\gamma_{2} d_{2 x}+\gamma_{3} d_{3 t}+\gamma_{4} d_{4 t}+\gamma_{5} d_{s t}+\varepsilon_{t}$

where:

$\mathbf{R}_{\mathbf{t}} \quad=$ the return for the S\&P portfolio;

$\alpha \quad=E$ (Monday retum);

$\gamma_{2} \ldots \gamma_{5}=$ the difference between the $\mathrm{E}$ (Monday retum) and $E$ (other day retum); and

$d_{2} \ldots d_{s_{t}}=$ dummy variables for days, Tuesday to Friday.

If the trading time hypothesis is correct, then the estimates $\gamma_{2} \ldots \gamma_{5}$ will be close to zero. In addition, a F-test for joint significance of the dummy variables would be insignificant.

The second model that French (1980: 61) develops is for the continuous time hypothesis:
$R_{t}=\alpha\left(1+2 d_{1 t}\right)+\gamma_{2} d_{2 t}+\gamma_{3} d_{3 t}+\gamma_{4} d_{4 t}+\gamma_{5} d_{5 t}+\varepsilon_{t}$

where:

$\mathrm{d}_{\mathrm{lt}} \quad=$ a dummy variable representing Monday.

In this model, $\alpha$ represents one third of the expected return for Monday and $\gamma_{2} \ldots \gamma_{5}$ represents the difference between $\alpha$ and the other days' expected returns. If the trading time hypothesis is correch a F-test for the hypothesis $\gamma_{2} \ldots \gamma_{5}$ $=0$ would be insignificant. French $(1980 ; 62)$ presents the results of these regressions and concludes that the evidence is inconsistent with both the continuous time hypothesis and the trading time hypothesis. Gibbons \& Hess (1981) report similar findings using a similar methodology with the Standard and Poor 500 and the CRSP equally weighted and value weighted portfolios, over the period 1962-1978.

Using the Rand Daily Mail 100 Industrial index for the period 1978-1980 and the JSE Overall Actuaries Index for the period 1980-1983, Bhana (1985: 9), replicating French's (1980:60-61) methodology, finds much the same results. For the readers' convenience, a summary of Bhana's (1985: 8) Table 1 is reproduced here.

The Monday effect can be clearly seen. The difference between the Monday standard deviation and the average for the other four days is approximately 14\%. Although the Monday effect can be seen from examining the entire period, in fact the effect was very slight. The t-statistic that he reports for the Monday effect is barely greater than two. In addition, Bhana (1985) does not adjust the daily returns to account for dividends. Bhana (1985: 9) presents the results of the French (1980) regressions and comes to the same conclusions as does French (1980).

Bhana (1985: 10) interprets his results as evidence that the JSE price mechanism is inefficient, he states further that the Monday effect 'cannot be reconciled with (an) efficient pricing mechanism'. This is a particularly strong statement, which in our opinion can only be made if the cause of the Monday effect is known - only then is it possible to determine whether or not the Monday effect is a violation of the EMH or not. There is no reason why Monday retums cannot be different under the EMH. Although the Monday effect appears to violate (2) above, it is not necessarily a violation of that theory. An economic model that does contain such a restriction is the capital asset pricing model. Under the CAPM, returns are related to systematic risk. It is unlikely that systematic risk is related to the day of the week. As Merton Miller has stated while discussing the various stock market anomalies, 'Either CAPM is wrong, or efficientmarket theory is wrong. Clearly, the efficient market theory is the dominant one' (quoted in Rohrer, 1985: 75).

The cause of the Monday effect is unknown or at least, not agreed upon. Potential causes such as a closed market

Table 1 Summary of Bhana's results

\begin{tabular}{lrllll}
\hline $1978-1983$ & Monday & Tuesday & Wednesday & Thursday & Friday \\
\hline Mean & -0.1192 & 0.0865 & 0.2299 & 0.1705 & 0.1446 \\
Standard dev. & 1.2429 & 0.9905 & 1.0931 & 1.2983 & 0.9804 \\
\hline
\end{tabular}


effect, settlement period effect and the length of the weekend have been investigated and rejected as causes of the Monday effect. Thaler (1987: 172) argues that there is legitimate concern about 'data mining'. One of the methods to circumvent this problem is replication of the studies using different time periods. In this article, we reinvestigate the Monday effect in a different time period, using a different methodology to the Bhana (1985) study.

Our reason for using a different methodology is that Connolly (1989: 133) has argued that seemingly significant results may be an artifact of the underlying (and, often, implicit) statistical assumptions. He argues further that much of the work on the weekend effect is based on elementary statistical methods that have strong assumptions. Connolly (1989: 135) argues that the assumptions that relate to normality, autocorrelation and heteroscedasticity are not met in financial markets. Connolly (1989) investigates the impact that these assumptions have on the results of the empirical investigations into the Monday effect and concludes that these flaws bias the results in favour of finding an anomaly.

After correcting these statistical flaws, Connolly (1989: 163-164), investigating the period 1963-1983 using the S\&P500 and both the equally weighted and value weighted CRSP indices, finds evidence that the Monday effect is very weak and that it 'disappeared' in the mid-1970s. He also reports that the size, stability and strength of the Monday effect is a function of the return measure.

\section{Methodology and results}

We used as our data set the All Share Index (ASI) for the calender years 1986-1991 inclusive. The ASI was drawn from the I-Net service. We calculated the weekday returns for the time series and conducted various tests on the data. These returns were not adjusted in any way and we did not assume that the Monday retum should be approximately three times the average weekday return. The results of this procedure can be seen in Table 2. It is obvious that there is a propensity for Monday returns to be negative. Although the figures are different from those in Bhana's (1985) Table 1, the same trend is discernable. The Monday retum is negative, the Wednesday return is large compared to the others and the Thursday return is the second largest.

As a first step we performed an ANOVA on the weekday returns. (ANOVA is a parametric test. It tests for differences in sample means assuming the observations are drawn from normally distributed populations with a common variance.) The ANOVA test determined that despite the negative returns, the Monday retums were not significantly different from the others. The null hypothesis that Monday is no different from any other day could not be rejected $(F=1.58$; $p=18 \%$ ). Given the size of our sample, it is remarkable that the null hypothesis cannot be rejected at any of the conventional levels of significance (see Miller, 1986: 3).

The returns used for Table 2 only constitute share price returns. As the investor expects to earn both capital gains and dividends from his investment, it is important to consider the returns that accrue to the investor by virtue of dividends. In common with many stock exchanges, most shares
Table 2 Weekday returns

\begin{tabular}{lccccc}
\hline $1986-1991$ & Monday & Tuesday & Wodnesday & Thursday & Friday \\
\hline Mean retums & -0.019 & 0.037 & 0.217 & 0.082 & 0.037 \\
Obervations & 295 & 305 & 305 & 301 & 295 \\
\hline
\end{tabular}

Returns are calculated as $\left(P_{1}-P_{0}\right) / P_{0}$

$\mathrm{DF}=4$ and 1496

on the JSE have last days to register (LDRs) on the last trading day of the week. We corrected for this omission in a rough and ready manner. Dividends on the shares making up the index were assumed to accrue evenly throughout the year on the last trading day of the week. The additional gain from the dividends were then added to the returm for the first trading day of the following week. (Part of the reward of holding shares over the weekend is the dividend.) The result of this exercise was to completely remove the negative return for Monday. As can be seen from Table 3, Monday's mean return is not even the lowest for the week. The Tuesday and Wednesday retums are marginally different from those in Table 1 because they do on occasion represent the first trading day of the week. Although the lack of a negative for Monday would indicate that there is no Monday effech, we still conducted an ANOVA (see Table 3).

The results were unsurprising - the hypothesis that Monday is no different from any other day could not be rejected $(\mathrm{F}=1.13 ; \mathrm{p}=34 \%)$.

In addition to the ANOVA on raw and dividend adjusted returns, we decided to perform a $\chi^{2}$ test. This test determines whether or not the observations in the data set have the same distributions. The results for the $\chi^{2}$ test on the unadjusted returns can be seen in Table 4 and the results for the adjusted data can be seen in Table 5 . In these tables we have disaggregated the average price movements into discrete intervals. The columns in the tables in fact represent the frequency distributions for each day. In both cases, even for a $p$-value of $25 \%$, the hypothesis of equal distribution of returns cannot be rejected. On the basis of the ANOVA and the $\chi^{2}$ test we can safely conclude that the Monday effect does not exist on the JSE. The Monday retum comes from a distribution that has the same mean and distribution as all the other days (see Tables 4 and 5).

It is important to realize that this conclusion can only be reached if the trading time hypothesis, and not the continuous time hypothesis, holds true. Shown in Table 6 are the results if we assume the continuous time hypothesis to be

Table 3 Weekday returns adjusted for dividends

\begin{tabular}{lccccc}
\hline 1986-1991 & Monday & Tuesday & Wednesday & Thursday & Friday \\
\hline Mean retums & 0.057 & 0.040 & 0.218 & 0.082 & 0.037 \\
Observations & 295 & 305 & 305 & 301 & 295 \\
\hline
\end{tabular}

Retums are calculated as $\left(\mathbf{P}_{1}-\mathbf{P}_{\mathbf{0}}+\mathrm{D}_{1}\right) / \mathbf{P}_{\mathbf{0}}$

$\mathrm{DF}=4$ and 1496 
Table $4 \chi^{2}$ test on unadjusted returns

\begin{tabular}{lllllll}
\hline Orewm & Monday & Tuesday & Wednesday & Thursday & Friday & Total \\
\hline$>1.25$ & 32 & 31 & 47 & 33 & 31 & 174 \\
$>1$ & 19 & 17 & 23 & 17 & 10 & 86 \\
$>.75$ & 15 & 21 & 24 & 19 & 16 & 95 \\
$>.50$ & 23 & 28 & 25 & 31 & 32 & 139 \\
$>.25$ & 29 & 31 & 29 & 32 & 29 & 150 \\
$>0$ & 24 & 37 & 24 & 24 & 25 & 134 \\
$>-.25$ & 44 & 36 & 37 & 46 & 36 & 199 \\
$>-.50$ & 21 & 27 & 28 & 29 & 36 & 141 \\
$>-.75$ & 30 & 24 & 20 & 23 & 27 & 124 \\
$>-1$ & 16 & 14 & 15 & 14 & 21 & 80 \\
$<-1$ & 42 & 39 & 33 & 33 & 32 & 179 \\
\hline Total & 295 & 305 & 305 & 301 & 295 & 1501 \\
\hline
\end{tabular}

$\chi^{2}=33.50, \mathrm{df}=40$

Table $5 \chi^{2}$ test on adjusted returns

Forecum Monday Tuesday Wednesday Thursday Friday Toal

\begin{tabular}{llllllr}
\hline$>1.25$ & 36 & 31 & 47 & 33 & 31 & 178 \\
$>1$ & 19 & 17 & 23 & 17 & 10 & 86 \\
$>.75$ & 14 & 21 & 24 & 19 & 16 & 94 \\
$>.50$ & 27 & 29 & 25 & 31 & 32 & 144 \\
$>.25$ & 28 & 30 & 29 & 32 & 29 & 148 \\
$>0$ & 39 & 39 & 24 & 24 & 25 & 151 \\
$>-.25$ & 31 & 34 & 37 & 46 & 36 & 184 \\
$>-.50$ & 19 & 27 & 28 & 29 & 36 & 139 \\
$>-.75$ & 29 & 24 & 20 & 23 & 27 & 123 \\
$>-1$ & 14 & 14 & 16 & 14 & 21 & 79 \\
$<=-1$ & 39 & 39 & 32 & 33 & 32 & 175 \\
\hline Total & 295 & 305 & 305 & 301 & 295 & 1501 \\
\hline
\end{tabular}

$\chi^{2}=37.92:$ df $=40$

true - i.e. the Monday retums are divided by three. (The reason for this being that by the continuous time hypothesis the Monday retum should be three times as great as any other day.) The result is a $\chi^{2}$ which is significant at almost any level (see Table 6).

Table 6 Monday compressed data (unadjusted)

\begin{tabular}{|c|c|c|c|c|c|c|}
\hline \%oretum & Monday & Tuesday & Wednesday & Thursday & Friday & Total \\
\hline$>.75$ & 9 & 69 & 94 & 69 & 57 & 298 \\
\hline$>.50$ & 20 & 28 & 25 & 31 & 32 & 136 \\
\hline$>.25$ & 37 & 31 & 29 & 32 & 29 & 158 \\
\hline$>0$ & 76 & 37 & 24 & 24 & 25 & 186 \\
\hline$>-.25$ & 95 & 36 & 37 & 46 & 36 & 250 \\
\hline$>-.5$ & 34 & 27 & 28 & 29 & 36 & 154 \\
\hline$>-.75$ & 11 & 24 & 20 & 23 & 27 & 105 \\
\hline$\ll-75$ & 13 & 53 & 48 & 47 & 53 & 214 \\
\hline Total & 295 & 305 & 305 & 301 & 295 & 1501 \\
\hline
\end{tabular}

$\chi^{2}=214.44 ; \mathrm{df}=28$
It is possible to create a Monday effect once we assume that the continuous time hypothesis is an accurate descriptor of reality. This effect may not be noticeable when using a regression-type analysis. This is due to the fact that the mean, being close to zero, would not be overly affected by this procedure. However, as can be seen by comparing the Monday column in Tables 4 and 6, it does affect the distribution of returns.

In order to illustrate this point, we took the 'Tuesday' returns and replicated them across the five columns, Monday to Friday. We then divided the returns in the 'Monday' column by three. The result is a 'Monday' effect which is simply an artefact of the assumptions (see Table 7).

This ability to create a Monday effect, based on an assumption, leaves us with having to decide which is a better descriptor of reality:

- the trading time hypothesis and no Monday effect; or,

- the continuous time hypothesis with a significant Monday effect?

We submit that the former is more probable for the following reasons:

- there is no theoretical reason or explanation for the existence of a Monday effect;

- if the continuous time hypothesis is true, it is unlikely that it would be exactly offset by the Monday return; and - an examination of the Monday column in Table 6 shows that the $\chi^{2}$ large statistic arises because the Monday returns are 'compressed' to the centre as a result of being divided by three. This is precisely what you would expect if the underlying distributions were, in fact, identical.

We are not suggesting that there never was a Monday effect. Our own research using American data shows that, especially in the sixties and seventies, there was a highly significant Monday effect even under the trading time hypothesis. Unfortunately, we do not have South African data going back beyond 1986 . We are able to corroborate Connally's (1989) point that the methodology used in previous studies is biased towards finding an anomaly.

\section{Implications}

Primarily, there are two broad implications for investors that can be drawn from this research. The first relates to the capital asset pricing model and the second refers to option

Table 7 Tuesday data (unadjusted)

\begin{tabular}{lrrrrrr}
\hline \%oretum & Monday & Tuesday & Wednesday & Thursday & Friday & Toul \\
\hline$>.75$ & 7 & 69 & 69 & 69 & 69 & 283 \\
$>.50$ & 17 & 28 & 28 & 28 & 28 & 129 \\
$>.25$ & 45 & 31 & 31 & 31 & 31 & 169 \\
$>0$ & 96 & 37 & 37 & 37 & 37 & 244 \\
$>-.25$ & 87 & 36 & 36 & 36 & 36 & 231 \\
$>-.5$ & 29 & 27 & 27 & 27 & 27 & 137 \\
$>-.75$ & 16 & 24 & 24 & 24 & 24 & 112 \\
$<=-.75$ & 8 & 53 & 53 & 53 & 53 & 220 \\
\hline Total & 305 & 305 & 305 & 305 & 305 & 1525
\end{tabular}

$\chi^{2}=204.05 ; \mathrm{df}=28$ 
pricing models. Other implications relate to the profitability of trading rules.

The criticisms that have been levelled against the CAPM rest on two legs:

- the CAPM cannot be tested (see Roll, 1977); and,

- there appear to be other factors such as firm size and day

of the week that systematically affect share retums.

With this article we find that the Monday effect has disappeared from the pattern of JSE returns. As such the second criticism that can be levelled against the CAPM is irrelevant within the South African context. Thus there may be an important role for that model on the JSE. It makes research into why the JSE is different from other markets necessary.

The trading time hypothesis has relevance to the pricing of share index options. Compound interest works in continuous time. The net result is that, if the trading time hypothesis is an accurate description of reality, the Black-Scholes pricing model and the Binomial model would tend to overprice options. This is due to the fact that compound interest accrues during weekends but, on average, no equity growth occurs.

Much has been made of the argument that the Monday effect is not an exploitable market inefficiency. While portfolio 'churning' in order to exploit a potential Monday effect would not be profitable, a simple rule such as 'Defer Friday's purchases to Monday' would enable investors to earn extra returns without incurring additional transaction costs. Since the investor is not rewarded for holding shares over the weekend, he may as well defer purchases to Monday, thus earning two days of interest in the interim.

The question arises as to why investors do not follow this rule and arbitrage the profit away? We cannot be certain, but we suggest the following:

- the gain from deferring purchases for a weekend is small - a one time additional return of about $0.03 \%$ during the period 1986-91. This is insignificant given the inherent risks of equity investment; and

- the JSE is a thin market. A substantial investor wishing to build up a position in a security often has no choice but to take what he can get when he can get it. To do otherwise, at least in the perception of most investors, may be to run the risk of 'missing the bus'.

\section{Conclusion}

In this article, we have reinvestigated the Monday effect on the JSE. By using a different methodology to French (1981) and Bhana (1985), we have been able to come to a number of conclusions. Perhaps the most important finding is that statistical assumptions may produce results which, while seeming significant, are an artefact of a particular model.
The economic conclusions are that firstly the Monday effect appears to have vanished. Secondly, the trading time hypothesis seems a betler description of reality than the continuous time hypothesis. To put it another way, weekends do not exist for equity markets and no retums occur during this 'dead' time. In theory certain trading rules may yield extraordinary profits. In practice they are insignificant and, in a thin market, may be unobtainable.

Future research, based on the results reported in this article could concentrate on why the JSE does not exhibit any of the anomalies that have been reported on other markets. Certainly researchers should be aware of the possibility of 'discovering' anomalies that are functions of the statistical methodology employed. A second area of research could investigate the impact that weekends have on option prices.

\section{References}

Bhana, N. 1985. 'The Monday effect on the Johannesburg Stock Exchange', S.A.J. Bus. Manage., Vol. 16, No. 1: 7-11.

Bradfield, D. 1989. 'A review of capital market theory from a South African perspective', De Ratione, Vol. 3, No. 1: 2-7.

Connolly, R. 1989. 'An examination of the robustness of the weekend effect', Journal of Financial and Quantitative Ana. lysis, Vol. 24, No. 2: 133-169.

Fama, E. 1965. 'The behaviour of stock-market prices', Journal of Business, Vol. 38, No. 1: 34-105.

Fama, E. 1970. 'Efficient capital markets: A review of theory and empirical work', Journal of Finance, Vol. 25, No. 2: 383-417. Reproduced in: S. Archer \& C. D'Ambrosio. (eds.). The theory of business finance: $A$ book of readings. Third Edition. London: MacMillan Press, pp. 183-221.

French, K. 1980. 'Stock returns and the weekend effect', Journal of Financial Economics, Vol.8: 55-69.

Gibbons, M. \& Hess, P. 1981. 'Day of the week effects and asset returns', Journal of Business, Vol. 54, No. 4: 579-596.

Miller, R. 1986. Beyond ANOVA, basics of applied statistics. New York: John Wiley.

Page, M. \& Palmer, F. 1991. 'The relationship between excess returns, firm size and eamings on the Johannesburg Stock Exchange', S.A.J. Bus. Manage., Vol. 22, No. 3: 63-73.

Rohrer, J. 1985. 'Ferment in academia', Institutional Investor, July: 69-78.

Roll, R. 1977. 'A critique of the asset pricing theory's tests: Part I: On past and potential testability of the theory', Journal of Financial Economics, Vol. 4: 129-176.

Seligman, D. 1983. 'Can you beat the stock market?', Fortune International, Dec. 26: 82-97.

Thaler, R. 1987. 'Seasonal movements in security prices II: Weekend, holiday, turn of the month, and intraday effects', Economic Perspectives, Vol. 1, No. 2: 169-177. 